\title{
Responses of Cancer Cells Induced by Photodynamic Therapy
}

\author{
Toshihiro Kushibiki, PhD*, Takeshi Hirasawa, MSc, Shinpei Okawa, PhD and \\ Miya Ishihara, $\mathbf{P h D}$ \\ Department of Medical Engineering, National Defense Medical College, Japan
}

Submitted July 2012. Accepted for publication November 2012.

\begin{abstract}
Photodynamic therapy (PDT) involves the administration of a photosensitizer, followed by local irradiation of tumor tissues using a laser of an appropriate wavelength to activate the photosensitizer. Since multiple cellular signaling cascades are concomitantly activated in cancer cells exposed to the photodynamic effect, understanding the responses of cancer cells to PDT will aid in the development of new interventions. This review describes the possible cell-death signaling pathways initiated by PDT. In addition, we describe our latest findings regarding the induction of expression of miRNAs specific to apoptosis in cancer cells and the induction of antitumor immunity following PDT against cancer cells. A more detailed understanding of the molecular mechanisms related to PDT will potentially improve long-term survival of PDT treated patients.
\end{abstract}

Keywords: photodynamic therapy, cancer, cell signaling, miRNA, tumor immunity

\section{INTRODUCTION}

Photodynamic therapy (PDT) is a photochemical modality approved for the treatment of various cancers and diseases in which neovascularization occurs [1, 2]. The PDT process consists of injecting a photosensitizer, which selectively accumulates at the lesion site, followed by local irradiation of the tumor with light of an appropriate wavelength to activate a specific drug [3]. Irradiation leads to the generation of singlet oxygen and other reactive oxygen species [4]. A simplified energy-level diagram of the possible pathways for energy absorption and dissipation is shown in Figure 1 [1]. The mechanism of PDT action on tumors is shown in Figure 2.

PDT is being considered not only as palliative therapy, but also as a treatment option for early skin, lung, cervical, and esophageal cancers as well as basal cell carcinomas.

*Corresponding author: Toshihiro Kushibiki, Department of Medical Engineering, National Defense Medical College, Japan. 3-2 Namiki, Tokorozawa, Saitama 359-8513, Japan Phone: +81-4-2995-1596: Fax: +81-42996-5199. E-mail: toshi@ndmc.ac.jp. Other authors: hirasawa@ndmc.ac.jp; okawa@ndmc.ac.jp; miyaishi@ndmc.ac.jp 


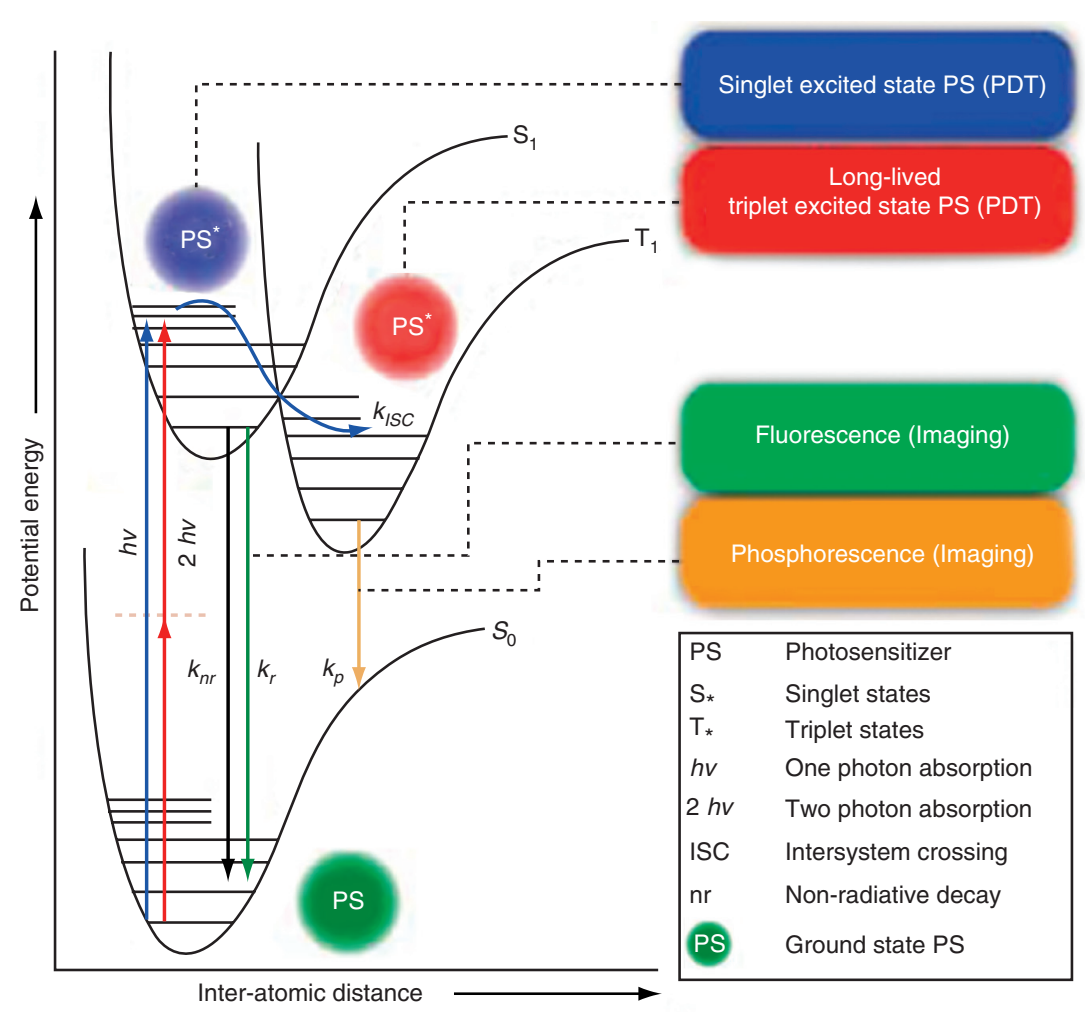

Figure 1. Perrin-Jablonski energy diagram for a photosensitizer (PS) molecule. Absorption of a photon causes the absorbing molecule to be electronically excited ( $\mathrm{S}_{n}$, singlet states; $\mathrm{T}_{n}$, triplet states). $\mathrm{S}_{1}$ may react with neighboring molecules, transition to a different excited state $\left(T_{1}\right)$, or relax to $S_{0} . T_{1}$ is longer-lived than $S_{1}$; consequently, the triplet state often mediates the biologically important reactions. $\mathrm{T}_{1}$ can initiate photochemical reactions directly, yielding free radicals, or transfer energy to oxygen molecules through collision, potentially resulting in ${ }^{1} \mathrm{O}_{2}$-mediated photo-oxidative reactions. The ${ }^{1} \mathrm{O}_{2}$-mediated photodynamic mechanism is generally accepted as a mode of PDT-induced cytotoxicity. Reproduced with permission from [1]. Copyright: American Chemical Society (2010).

Currently, PDT has been approved for localized diseases and precancerous lesions such as bladder cancers, pituitary tumors, and glioblastomas [6, 7]. Furthermore, numerous ongoing clinical studies have been designed to optimize the conditions for PDT; subsequently, PDT has been approved in several countries. However, one inherent consequence of PDT is local hypoxia, which can arise either directly, from oxygen consumption during treatment [8-10], or indirectly, from the destruction of tumor vasculature as a result of effective treatment $[11,12]$. Hypoxia is a major stimulus for 


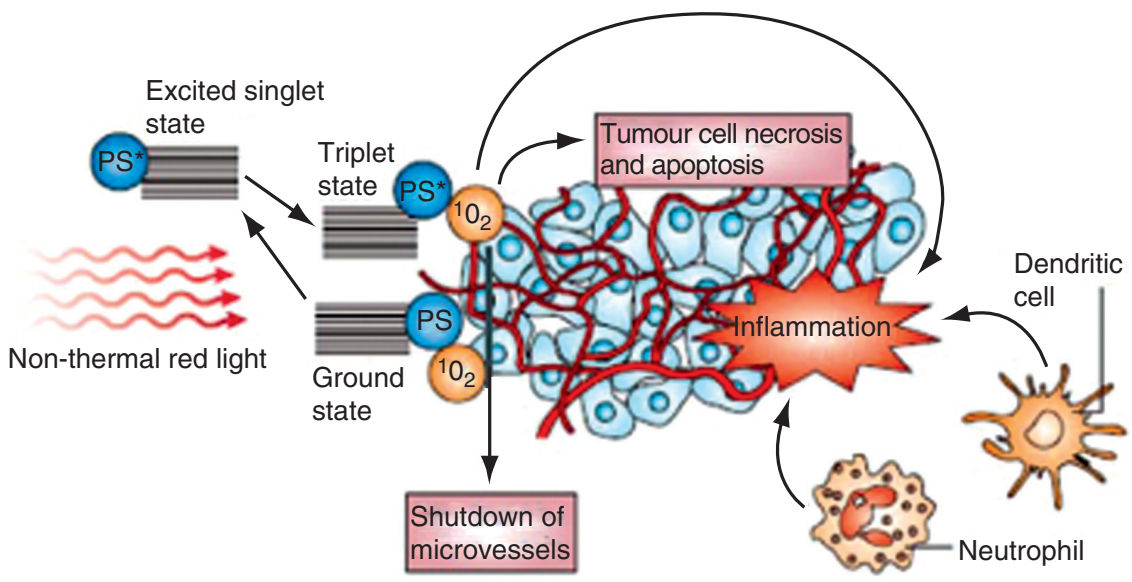

Figure 2. The mechanism of PDT action on tumors. Reactive singlet oxygen $\left({ }^{1} \mathrm{O}_{2}\right)$ can directly kill tumor cells by inducing necrosis and/or apoptosis, destroy tumor vasculature, and produce an acute inflammatory response that attracts leukocytes such as dendritic cells and neutrophils. Reproduced with permission from [5]. Copyright: Nature Publishing Group (2006).

angiogenesis, via its stabilization of the hypoxia-inducible factor-1 $\alpha$ (HIF-1 $\alpha$ ) transcription factor $[13,14]$. HIF-1 is a heterodimeric complex of two helix-loop-helix proteins, HIF- $1 \alpha$ and HIF-1 $\beta$ (ARNT). ARNT is constitutively expressed, whereas HIF$1 \alpha$ is rapidly degraded under normoxic conditions. Hypoxia induces the stabilization of the HIF- $1 \alpha$ subunit, which in turn allows formation of the transcriptionally active protein complex. A number of HIF-1-responsive genes have been identified, including those encoding vascular endothelial growth factor (VEGF), erythropoietin, and glucose transporter-1 [15, 16]. Following PDT, increases in VEGF secretion and angiogenic responses stimulated via HIF-1 pathways have been documented in vivo [17-20]. VEGF induction could contribute to tumor survival and regrowth, and therefore could represent one of the factors that prevent PDT from achieving its full tumoricidal potential. Recent evidence indicates that PDT can destroy cancer cells directly by the efficient induction of apoptotic as well as non-apoptotic cell-death pathways. The identification of the molecular effectors that regulate the crosstalk between apoptosis and other major cell-death programs is an area of intense research in cancer therapy. Detailed biological mechanisms for killing of cancer cells by PDT, including signaling cascades, have been proposed by several researchers [21-25], but a few recent reports have focused on the response of cancer cells following PDT [26, 28].

In this review article, we summarize 1) the mechanism of cancer-cell death after PDT, 2) expression of a microRNA (miRNA) specific to cancer-cell apoptosis after PDT, and 3) the induction of tumor immunity as a result of PDT against cancer cells. Section 2 reviews the reported biological mechanisms for cancer-cell killing by PDT, including the multiple cell signaling cascades that are concomitantly activated in cancer 
cells exposed to the photodynamic effects. In Section 3, we summarize our latest results regarding increased expression of an apoptosis-specific miRNA following PDT. Section 4 summarizes the effect of PDT on the anti-tumor immune response. This review article aims at contributing to a better understanding of PDT-related mechanisms, which will in turn potentially improve long-term survival of PDT treated patients.

\section{MOLECULAR MECHANISM OF CELL DEATH INDUCED BY PDT}

The direct destruction of cancer cells (necrosis) by PDT is caused by irreversible damage to the plasma membrane and intracellular organelles, such as the mitochondria, lysosomes, Golgi apparatus, and endoplasmic reticulum (ER). Necrosis may occur only after high photosensitizer and/or light doses, but these are generally to be avoided in order to suppress damage to normal tissues. The mechanisms of PDT-induced apoptosis have been described by many researchers. Apoptosis, or programmed cell death, is one mechanism that mediates toxicity in the target tissue following PDT [23]. Apoptosis involves a cascade of molecular events leading to orderly cellular death without an inflammatory response [29-31]. The initiation of apoptosis involves a complex network of signaling pathways, both intrinsic and extrinsic to the individual cell, which are regulated in part by pro- and anti-apoptotic factors [29]. Upon absorption of one or more photons, the excited photosensitizer undergoes one of two possible reactions (type I or/and II) with a neighboring oxygen molecule, yielding reactive oxygen species (ROS) [32]. These ROS oxidize various cellular substrates, affecting cellular functions and resulting in cell death. The ROS that are produced during PDT destroy tumors by multiple mechanisms. PDT has a direct effect on cancer cells, producing cell death by necrosis and/or apoptosis, in contrast to most conventional cytotoxic agents, which usually only trigger apoptotic cell death. The initial damage can involve different molecules, ultimately leading to activation of specific death pathways. Mitochondrialocalized photosensitizers can cause immediate and light-dependent photodamage to mitochondrial components such as the anti-apoptotic Bcl-2, Bcl-xL, and the other proapoptotic proteins, prompting the release of caspase-activating molecules [33]. Photosensitizers that accumulate in the lysosomes or ER induce Bax-mediated caspase activation (Figure 3).

Another important cellular factors induced by PDT and released from necrotic tumor cells is heat-shock protein 70 (Hsp70) [34]. Hsp70 is significantly induced after stress; when it remains within the cell, it chaperones unfolded proteins and prevents cell death by inhibiting the aggregation of cellular proteins. PDT induces rapid cytochrome c release, initiating an apoptotic cascade via an activation of different caspases. Hsp70 directly binds to the caspase-recruitment domain of apoptotic-protease activating factor 1 (Apaf-1), thereby preventing the recruitment of Apaf-1 oligomerization and association of Apaf-1 with procaspase 9. These properties not only enable intracellular Hsp70 to inhibit cancer cell death by apoptosis, but also promote the formation of stable complexes with cytoplasmic tumor antigens. These antigens can then either be expressed at the cell surface or escape intact from dying necrotic cells to interact with 


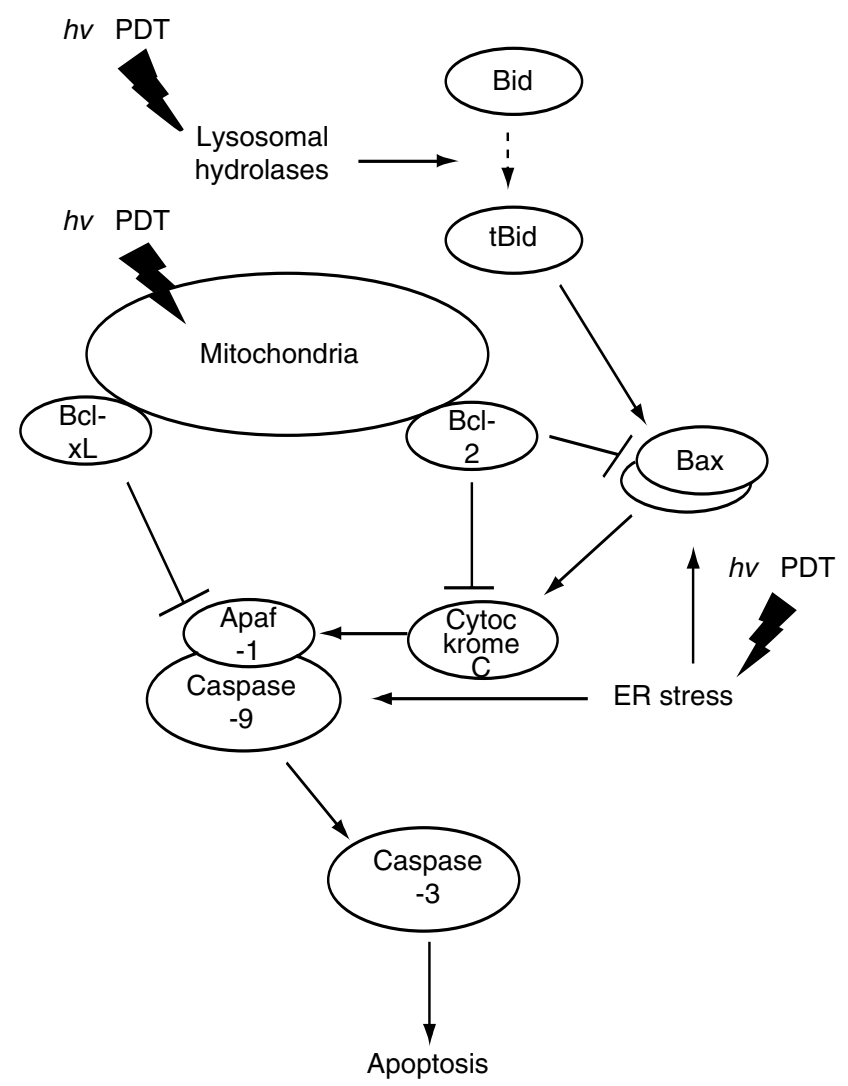

Figure 3. Representative signaling pathways of apoptosis induced by PDT. Depending on the nature of the photosensitizer and its intracellular localization, the initial photodamage can involve different molecules, with the consequent activation of specific death pathways that converge on mitochondria. Mitochondria-localized photosensitizer can cause immediate and light-dependent photodamage to the anti-apoptotic Bcl-2 and $\mathrm{Bcl}-\mathrm{xL}$ proteins, prompting the release of caspase-activating molecules. Lysosomal hydrolases and ER stress also induce Baxmediated caspase activation.

antigen-presenting cells and thereby stimulate an anti-tumor immune response. The mechanism of cell death following PDT has been thoroughly summarized in the literature [21-25]. A better understanding of the molecular differences between apoptosis and necrosis, and identification of the crosstalk between these programs, will certainly prove crucial to the development of new PDT modalities aimed at increasing the efficiency of cancer-cell killing. 


\section{PDT INDUCES EXPRESSION OF MIRNA-210 AND -296 IN CANCER CELLS}

miRNAs constitute an abundant class of short ( 22 nt) regulatory non-coding RNAs that are widely expressed in all metazoan eukaryotes and highly conserved among a variety of organisms. miRNAs are encoded by genes that are presumably transcribed into single or clustered primary transcripts, and subsequently processed to produce mature miRNAs. Mature miRNAs are incorporated into a ribonucleoprotein complex, the RNA-induced silencing complex (RISC), and guide the RISC to their target mRNAs. Together, RISC and miRNAs mediate the down-regulation of target genes by mRNA cleavage or translational repression [35].

Human cancer is associated with changes in miRNA expression. The pattern of miRNA expression varies dramatically across tumor types, and miRNA profiles reflect the developmental lineage and differentiation state of a tumor [36]. miRNA is also likely to play critical roles in various aspects of hematopoiesis, including the differentiation of hematopoietic stem/progenitor cells, as well as in events that lead to hematological disorders. Nonetheless, very few miRNA expression patterns for specific diseases are available. Moreover, no profiles of miRNA expression after PDT have reported. We have shown that an miRNA specific to apoptosis is expressed at increased levels in HeLa cells in response to PDT using talaporfin sodium as a photosensitizer [37]. Our study was the first to characterize miRNA expression levels following PDT. In our experiments, miR-210 and miR-296 expression levels increased significantly 1 hour after PDT in cells treated with $50 \mu \mathrm{g} / \mathrm{mL}$ talaporfin sodium, relative to the control group (i.e., talaporfin sodium concentration of $0 \mu \mathrm{g} / \mathrm{mL}$ ) as shown in Figure 4. However, the expression levels of other miRNAs, e.g., miR-7, miR-148a, miR-204, and miR-216, were indistinguishable from those of the control group after PDT.

miR-210 is the most prominent miRNA consistently stimulated under hypoxic conditions [38]. Because an inherent consequence of PDT is hypoxia and stabilization of intracellular HIF [6], miR-210 expression was observed related to its hypoxic effect in this study. Giannakakis et al. reported evidence for the involvement of the HIF signaling pathway in miR-210 regulation. To study the biological impact of a partial or complete loss of miR-210 functions, they also identified putative mRNA targets of miR-210. According to their report, miR-210 targets important regulators of transcription, cell metabolism, differentiation, and development, i.e., processes that are critically affected by hypoxia [38]. The identification of key regulators of important cellular processes among miR-210 target mRNAs and the high frequency of gene copy aberrations in tumors, underscore the involvement of miR-210 in oncogenesis and highlight miR-210 as a potential link between hypoxia and cellcycle control in cancer cells.

Würdinger et al. reported a role for miR-296 in promoting angiogenesis in tumors [39]. They showed that VEGF alone is capable of increasing miR-296 expression levels. Their results revealed an interesting feedback loop whereby VEGF induces miR296 expression, which targets the hepatocyte growth factor-regulated tyrosine kinase substrate (HGS), which in turn results in increased levels of VEGF receptor 2 and platelet-derived growth factor (PDGF) receptor $\beta$ protein, and hence an increased 

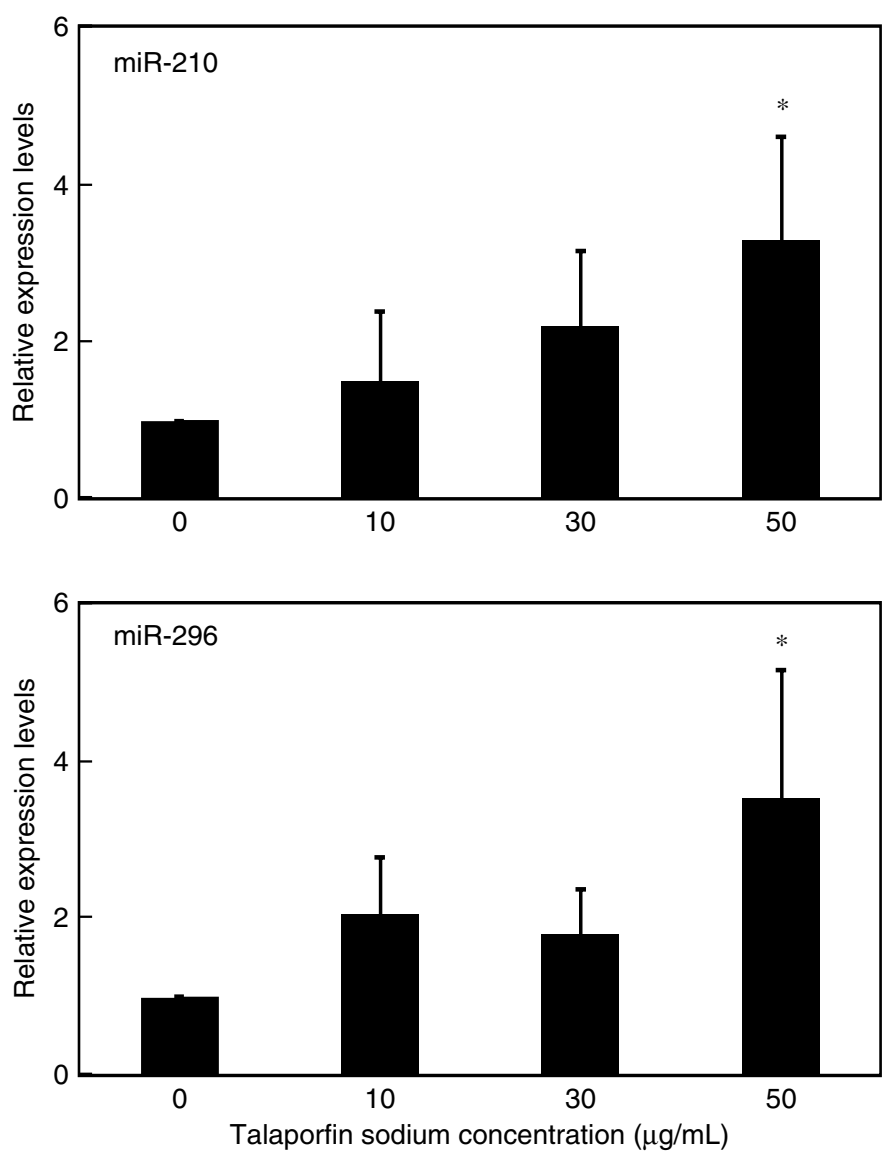

Figure 4. Expression of miR-210 and miR-296 after PDT in HeLa cells. miR-210 and miR-296 expression levels were significantly increased 1 hour after PDT $\left(60 \mathrm{~mW} / \mathrm{cm}^{2}, 90 \mathrm{sec}\right)$ in cells treated with $50 \mu \mathrm{g} / \mathrm{ml}$ talaporfin sodium relative to levels in the control group (i.e., talaporfin sodium concentration of $0 \mu \mathrm{g} / \mathrm{mL})\left(1 \times 10^{4}\right.$ cells/well $)$. The asterisk, $*$, indicates $\mathrm{p}<0.05$, a significant difference between the relative expression levels of PDT-treated cells and non-PDT-treated cells. All experiments were performed four times independently. All data are expressed as means \pm SD of four replicates from four experiments [37]. Copyright: Wiley-VCH Verlag GmbH \& Co. KGaA. Reproduced with permission (2010).

response to VEGF. Because increased VEGF sensitivity of cancer cells is one of the inherent consequences of PDT [18], our results suggest that inhibition of miR-296 expression should improve PDT efficacy [37]. Our study also suggested that hypoxia induced by PDT induces miR-210 expression, followed by an increase of expression of 
VEGF and miR-296 [37]. Hence, miR-210 and miR-296 expression levels represent markers for the efficacy of talaporfin sodium-mediated PDT in cancer cells.

Cheng et al. found that inhibition of miR-95, -124, -125, -133, -134, -144, -150, $-152,-187,-190,-191,-192,-193,-204,-211,-218,-220,-296$, and -299 resulted in a decrease in cell growth, whereas inhibition of miR-21 and miR-24 profoundly increased cell growth, in HeLa cells [40]. In addition, they found miRNA that increased observed levels of apoptosis (miR-7, -148, -204, -210, -216, and -296). Those data suggest that specific miRNAs are involved in the cell-death response.

\section{PDT INDUCES ANTI-TUMOR IMMUNITY}

In contrast to surgery, radiotherapy, and chemotherapy, which are mostly immunosuppressive, PDT causes acute inflammation, expression of heat-shock proteins, and invasion and infiltration of the tumor by leukocytes, and may increase the presentation of tumor-derived antigens to T cells [5]. In the case of necrosis, cytosolic constituents spill into the extracellular space through the damaged plasma membrane and provoke a robust inflammatory response. In contrast, these products are safely isolated by the intact membranes that initially persist in apoptotic cells, which are ultimately phagocytosed by macrophages. The acute inflammation caused by PDTinduced necrosis might potentiate immunity by attracting host leukocytes into the tumor and increasing antigen presentation (Figure 5) [5].

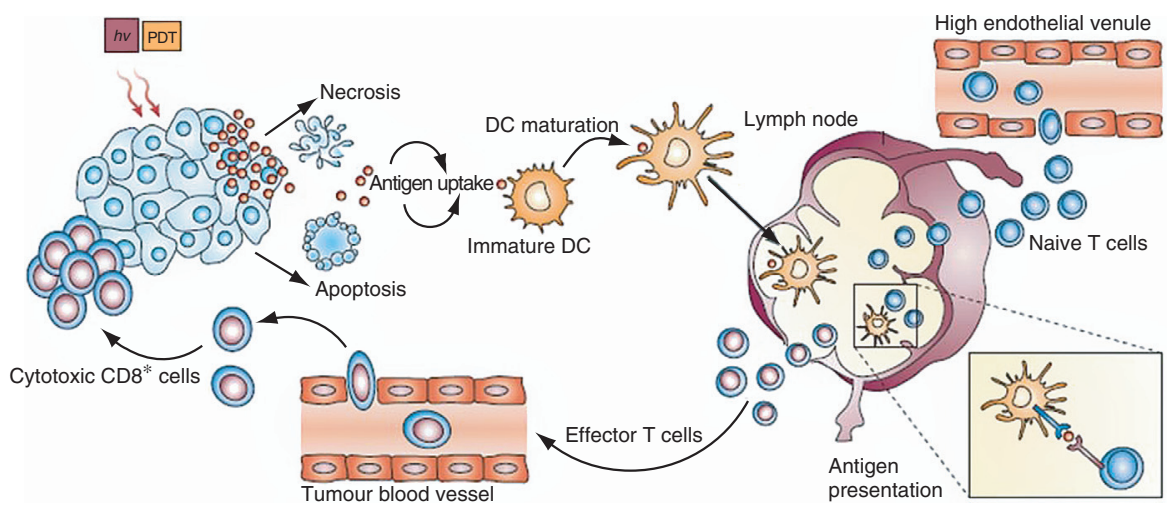

Figure 5. PDT induces activation of antigen-specific T cells. When light $(h v)$ is delivered to a photosensitizer-loaded tumor, it induces both apoptotic and necrotic cell death. These cells are phagocytosed by dendritic cells (DCs) that accumulated in response to the acute inflammatory response triggered by PDT. DCs mature after stimulation by cytokines, which are released at the site of inflammation, and home to the regional lymph nodes, where they present antigens to the T lymphocytes. Activated $\mathrm{T}$ lymphocytes become effector $\mathrm{T}$ cells, which are attracted by chemokines to migrate into the tumor and kill cancer cells. Reproduced with permission [5]. Copyright: Nature Publishing Group (2006). 
Korbelik et al. reported many results regarding the PDT-associated host response and its role in determining the therapeutic outcome. Numerous preclinical and clinical studies, to be addressed below, have demonstrated that PDT can influence the host immune response as well as the therapeutic outcome. The precise mechanisms that lead to potentiation versus suppression are unclear, but it appears that the effect of PDT on the immune system is dependent upon the treatment regimen, the area treated, and the type of photosensitizer used.

Fluence rate has a large impact on the host immune response to PDT. In PDT against angiosarcoma, lower fluence rate PDT results in better outcome; furthermore, the fluence rate per se, rather than the total light dose, is the more crucial determinant of the treatment outcome [41]. Specifically, PDT at lower fluence rates appears to activate the body's immune response against untreated lesions. Furthermore, in treatment of basal cell carcinoma, immune reactivity following PDT is inversely correlated with treatment area and light dose [42]. However, in other studies, higher-energy doses resulted in large increases in reactive oxygen intermediates (ROI) and production of factors that could contribute to complete eradication of tumors; furthermore, higher doses were associated with decreased activation of NF- $\kappa B$ and IL- $1 \beta$ production that could inhibit tumor progression [43].

To the extent that the effect of PDT on anti-tumor immunity is regimen-dependent, it is tightly linked to the degree and nature of inflammation induced by PDT [44]. Although the precise mechanism underlying PDT-regulated adaptive anti-tumor immunity remains unclear, a growing body of literature has characterized the effects of PDT on various branches of the innate and adaptive immune system. For example, immune recognition of Hip1 increased in patients whose basal cell carcinoma lesions were treated with PDT, and this increase in reactivity was significantly greater than reactivity observed in patients whose lesions were surgically removed [42].

The population of leukocytes that invades PDT-treated tumors includes neutrophils, which have been documented as inflammatory and immune effectors in PDT-treated mouse SCCVII tumors; in that model, IL-1 $\beta$ activity was critical for the therapeutic outcome, because its neutralization diminished the cure rates of PDT-treated tumors [45]. Neutrophil migration into treated tumors is associated with a transient, local increase in the expression of the chemokines macrophage inflammatory protein (MIP)-2 and $\mathrm{KC}$; a similar increase was detected in functional expression of adhesion molecules, e.g., E-selectin and intracellular adhesion molecule (ICAM)-1, and in both local and systemic expression of IL-6 [46]. In response to non-lethal PDT, tumors cells significantly upregulate a number of immune-related genes, including the genes encoding the chemokines CXCL2, CXCL3, and IL8/CXCL8 as well as IL6 and its receptor IL6R [47]. These chemokines can stimulate proinflammatory reactions, and IL6 and IL6R can also enhance tumor growth. Neutrophils also regulate the enhancement of antitumor immunity by PDT. By augmenting T-cell proliferation and/or survival, tumor-infiltrating neutrophils play an essential role in establishment of antitumor immunity following PDT, suggesting a mechanism by which neutrophils might affect antitumor immunity following other inflammation-inducing cancer therapies [48]. Neutrophils are also involved in the response to PDT in contexts other 
than cancer therapy. In a study of MRSA, although therapeutic PDT could not demonstrate direct bacterial killing, neutrophils accumulated in the infected joint space after PDT, and MRSA arthritis was reduced. With a preventive PDT preconditioning regimen, neutrophils quickly accumulated into the joint immediately after bacterial inoculation, suppressing bacterial growth and the establishment of infection [49].

For the generation of anti-tumor immunity, antigen presentation is crucial, and DCs are the most potent antigen-presenting cells. DCs pulsed with tumor-derived peptides, proteins, genes, or lysates, as well as DCs fused with cancer cells, have been studied as therapeutic cancer vaccines [50-58]. Although the methods involved are complex and costly to implement, promising results have been obtained in clinical trials in patients with advanced malignancies. These trials have shown DC-based vaccination to be well tolerated and capable of inducing tumor-specific T-cell responses and regression of metastatic disease. It is clear that induction of antitumor immunity after PDT is dependent upon induction of inflammation [59]. Mature DCs are critical for activation of tumor-specific $\mathrm{CD} 8^{+} \mathrm{T}$ cells and the induction of antitumor immunity [60]. In response to PDT, DCs are activated [46] and migrate to tumor-draining lymph nodes, where they are thought to stimulate T-cell activation [61]. Antigen presenting cells (APCs) isolated from PDT-treated mice exhibited an enhanced ability to stimulate T-cell proliferation and IFN-gamma secretion, suggesting that PDT resulted in increased APC activity [62]. PDT-mediated enhancement of antitumor immunity is believed to be due, at least in part, to stimulation of DCs by dead and dying tumor cells, suggesting that in vitro PDT-treated tumor cells may act as effective antitumor vaccines. A sudden appearance of a large number of PDT vaccine cells elicits host responses for securing their optimized clearance, which in addition to producing seminal acute phase reactants includes the engagement of glucocorticoid hormones. It is becoming increasingly clear that a consummate execution of this process of PDT vaccine cell removal is critical for tumor antigen recognition and the attainment of potent antitumor immune response [63].

DC activation by material derived from PDT-treated cells positively affects treatment outcomes. For example, using 5-aminolevulinic acid as a pro-drug, kinetically favorable biologic conversion to the photosensitive protoporphyrin IX, appropriate trafficking of syngeneic bone marrow-derived DCs injected into PDTtreated tumors within 15 min of completion of therapy, and improved survival over either modality alone [61]. Likewise, PDT tumor lysate-pulsed DC (PDT-DC) inhibited the growth of mammary EMT6 tumors to a greater extent than freeze/thawed tumor lysate-pulsed DC (FT-DC) or PDT tumor lysates; PDT-DC also showed significant anti-tumor effects against fully established (i.e., late-stage) solid tumors [64].

Mechanistic studies have shown that incubation of immature DCs with PDT-treated tumor cells leads to enhanced DC maturation and activation and an increased ability to stimulate T cells. PDT treatment resulted in the induction of apoptotic and necrotic cell death and expression of HSP27, HSP60, HSP72/73, HSP90, HO-1, and GRP78 in C-26 cells; immature DCs co-cultured with PDT-treated C-26 cells efficiently engulfed killed tumor cells, acquired functional features of maturation, and produced substantial amounts of IL-12 [65]. Furthermore, lysates from PDT-treated cells were able to activate DCs to express IL-12, and PDT effects on tumor cells alone were sufficient to 
generate an antitumor immune response, indicating that the direct tumor effects of PDT played an important role in enhancing the host antitumor immune response [66].

We have reported that PDT-generated cancer-cell lysate (from mouse Lewis Lung Carcinoma, LLC) induces secretion of IL- $1 \alpha$, IL-1 $\beta$, and IL-6 from DCs, suggesting that PDT-enhanced anti-tumor immunity is due in part to increased DC activation [67] and the host antitumor immune response [68]. To determine whether this enhancement was at least in part a consequence of the effects of PDT on cancer cells, we tested the immunogenicity of cancer-cell lysates generated by in vitro PDT treatment using talaporfin sodium as a photosensitizer. IL- $1 \alpha$, IL-1 $\beta$, and IL- 6 were most markedly increased, and TNF- $\alpha$ was decreased, in DC culture supernatants following this treatment (Figure 6A). These cytokines must have been secreted from DCs, because they were not detected in the cancer-cell lysates. The concentrations of other cytokines (with the exception of IL-2 and IL-12, which were below the detection limit of ELISA) were not changed relative to those of control cells. In parallel, cytokine levels were also examined in the supernatants of DC cultures treated with freeze/thaw-generated cancer cell lysates (Figure 6B). In these experiments, the levels of cytokines and growth factors secreted into the supernatant were unchanged after treatment with the freeze/thawgenerated lysates.

IL- $1 \alpha$, IL-1 $1 \beta$, and TNF- $\alpha$ were investigated in parallel because they are recognized inducers of IL-6 and act synergistically with IL- 6 to induce antitumor responses in mice $[69,70]$. We confirmed the enhancement of IL-6 secretion from cells after in vitro PDT, described earlier by Kick et al. [71]. Furthermore, as suggested by Kick et al., TNF- $\alpha$ does not seem to play a role in IL-6 induction by PDT, because the changes in IL-6 are neither preceded nor accompanied by similar changes in TNF- $\alpha$. PDT induces TNF- $\alpha$ in murine peritoneal macrophages in vitro [72], and a study by Anderson et al. [73] demonstrated up-regulation of TNF- $\alpha$ in keratinocytes by in vitro PDT using a phthalocyanine-derived photosensitizer. The decreased levels of TNF- $\alpha$ observed in our study might be related to the DCs used, given that the regulatory region of the TNF- $\alpha$ gene exhibits polymorphism [74]. It remains to be determined whether the enhanced generation of IL- 6 plays a role in the PDT-induced tumor response. Intratumoral injection of IL-6 or transduction of the IL- 6 gene into cancer cells can enhance tumor immunogenicity and inhibit tumor growth in experimental murine tumor systems [70, $75,76]$. Thus, PDT may enhance local antitumor immunity by upregulating IL-6 production in DCs, although the mechanisms by which this is achieved are not yet clear. Dougherty et al. [75] have suggested that IL-6 may further the recruitment of tumoricidal macrophages into the tumor bed. On the other hand, Mule et al. [70] have shown that IL-6-mediated tumor regression could be abrogated by in vivo depletion of either $\mathrm{CD}^{+}$or $\mathrm{CD}^{+}$T-cell subsets. Although this study did not examine T-cell responses, changes in T-cell function might occur, and we are presently addressing this issue using co-culture methods. In another study, elimination of IL-6 had no effect on innate cell mobilization into the treated tumor bed or tumor-draining lymph node, and did not affect primary antitumor T-cell activation by PDT; however, IL-6 does appear to negatively regulate the generation of antitumor immune memory and PDT efficacy against murine colon and mammary carcinoma models, in a manner that may be related to regulation of Bax protein expression [77]. 
(a)

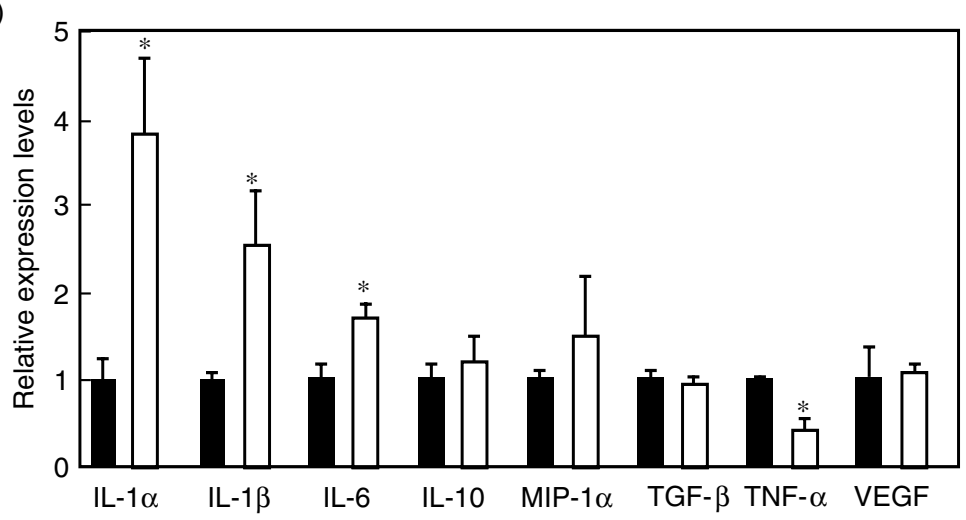

(b)

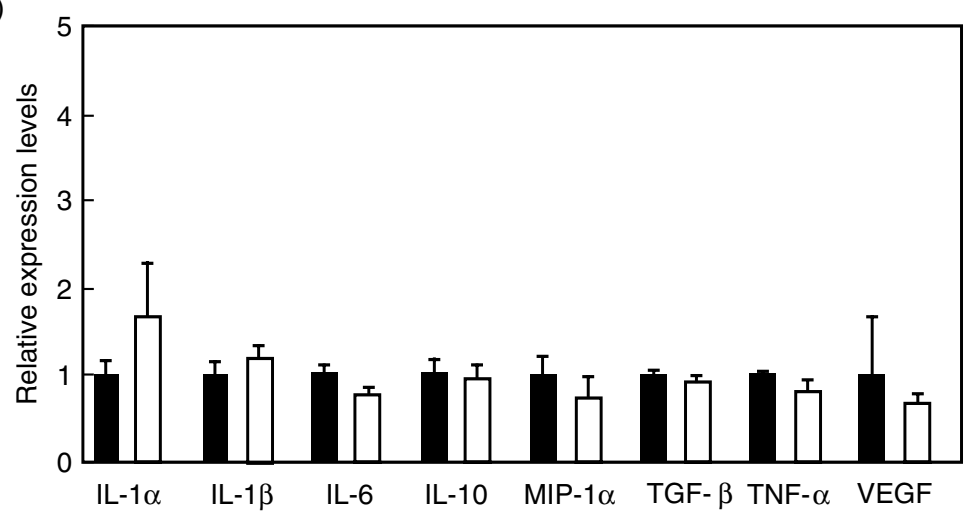

Figure 6. (A) PDT-generated cell lysates activate DCs. IL-1 $\alpha$, IL-1 $\beta$, and IL-6 were most markedly increased, whereas TNF- $\alpha$ was decreased, following the addition of lysates from PDT-treated cells to DC cultures (white bars) compared with that of stationary culture media from LLC cells (black bars); talaporfin sodium $(50 \mu \mathrm{g} / \mathrm{mL})$ was used as a photosensitizer in the PDT. By contrast, cytokine levels did not change after addition of freeze/thaw-generated cancer-cell lysates to DC cultures (white bars) compared with that of stationary culture media from LLC cells (black bars) (B). IL-2 and IL-12 secretion levels were below the detection limits of ELISA assays. $* \mathrm{p}<0.01$ : significant difference in levels between addition of PDT-generated lysates and addition of stationary culture media from LLC cells [67]. Copyright: e-Century Publishing Corporation. Reproduced with permission (2010).

Luna et al. [78] have shown in murine RIF cells in vitro that the early-response proteins c-fos and c-jun are induced by Photofrin; these gene products form the AP-1 transcription factor, which induces IL-6 expression [69, 71, 79]. Gollnick et al. [66] reported that vaccination with lysates from PDT-treated cancer cells elicits a tumor- 
specific immune response, as demonstrated by protection against subsequent tumor inoculation, induction of tumoricidal activity in the spleen, and increased numbers of IFN- $\gamma$-secreting splenic cells. These studies demonstrate that PDT can enhance the inherent immunogenicity of at least some cancer cells.

The nature of the activating factor in lysates from PDT-treated cancer cells is unknown, although there are several promising candidates. In determining the response to PDT-treated cells, surface-expressed proteins may play a crucial role. Photoreaction by a cell surface-bound photosensitizer was 10-fold more effective than photosensitizers localized to mitochondria or lysosomes; furthermore, high-dose intracellular, but not cell surface, photoreaction inactivated IL-1 and reduced fibroblast stimulation [80]. In the same study, the authors showed that epithelial cells released IL$1 \beta$ as the primary fibroblast-stimulatory activity under basal conditions. Intracellular IL-1 $\alpha$, externalized following photoreaction, accounted for most of the PDT-mediated fibroblast activation. Expression of IL-1 was subject to increase or loss during oncogenic transformation, resulting in altered alarm functions that could be mobilized by PDT. In vitro PDT significantly induces the MHC class I-related molecules, MICA, in Colo205 cells, but had no effect on MHC class I molecule expression. PDT also induced expression of NKG2D ligands (NKG2DL) following in vivo HPPH-PDT of a murine tumor. Induction of MICA corresponded to increased NK killing of PDT-treated tumor cells [81].

Macrophages co-incubated with PDT-treated SCCVII cells displayed elevated levels of both HSP70 and GRP94 on their surface and were stimulated to produce tumor necrosis factor (TNF) alpha, whose production was inhibited by the presence of antibodies against either HSP70, Toll-like receptors 2 and 4, or specific NF-KB inhibitor in the co-incubation medium [62]. Surface expression of heat shock proteins and complement opsonization were two distinctive features of PDT-treated cells that conferred avid immune recognition of vaccinated tumors and the development of a strong and effective antitumor adaptive immune response [82]. Complement genes $\mathrm{C} 3$, C5, and C9 become upregulated in tumors treated by PDT, but not in the host's liver; tumor-localized up-regulation of these genes can be largely attributed to monocytes/macrophages invading the treated lesion after PDT [83]. Lymphocytes isolated from PDT-treated animals were able to induce anti-tumor immunity in nude mice; however, the anti-glioma immunity fostered by PDT was inhibited in complement C3 knockout mice, indicating the requirement of the activities of complement $\mathrm{C} 3$ and $\mathrm{T}$ cells. $\mathrm{T}$ cells that produce cytokines, along with complement $\mathrm{C} 3$, may play crucial roles in mediating PDT-induced anti-glioma responses [84].

T cells play other important roles in determining the response to PDT. In a study of PDT against genital warts, the immunohistochemical pattern was dominated by dense $\mathrm{CD}^{+} \mathrm{T}$ lymphocytes infiltrating the superficial dermis, accompanied by an accumulation of Langerhans cells. Simultaneously, CD8 began to increase in the lesions of responding patients, and Langerhans cells seemed to migrate towards the dermis. $\mathrm{CD} 68^{+}$macrophages apparently did not participate in the immune inflammatory response [85]. Conversely, the immunosuppressive effects of phthalocyanine PDT in mice were mediated by $\mathrm{CD}^{+}$and $\mathrm{CD} 8^{+} \mathrm{T}$ cells and can be adoptively transferred to naive recipients. PDT-induced immunosuppression could be 
adoptively transferred with spleen cells from PDT treated donor mice to syngenic naive recipients and was mediated primarily by $\mathrm{T}$ cells, although macrophages were also found to play a role [86].

The implications of PDT-induced antitumor immunity and efficacious PDTgenerated vaccines are significant, and raise the exciting possibility of using PDT in the treatment of metastatic disease or as an adjuvant in combination with other anticancer therapeutic modalities. Several preclinical studies have demonstrated that PDT can control the growth of tumors present outside the treatment field, although other studies have failed to demonstrate control of distant disease following PDT. In one study, PDT was capable of destroying distant, untreated, established, antigenexpressing tumors in $70 \%$ of mice, while the remaining $30 \%$ escaped destruction due to loss of expression of tumor antigen; these PDT anti-tumor effects were completely abrogated in the absence of the adaptive immune response [87]. In another study, PDT activated the immune response against distant untreated tumors in recurrent angiosarcoma [88]. $\mathrm{CD}^{+} \mathrm{T}$ cell-mediated control of distant tumors following local PDT was independent of $\mathrm{CD}^{+} \mathrm{T}$ cells and dependent on natural killer (NK) cells. Local PDT treatment led to enhanced anti-tumor immune memory that was evident 40 days after tumor treatment and was independent of $\mathrm{CD} 4^{+} \mathrm{T}$ cells. $\mathrm{CD} 8^{+} \mathrm{T}$ cell control of the growth of lung tumors present outside the treatment field following PDT was dependent upon the presence of NK cells [89]. NK cells, T cells or macrophages in non-illuminated liver tumors in mTHPC-treated rats did not increase significantly when compared with tumors in rats without mTHPC treatment. No antitumor effect of a systemic immune response was present, as measured by the effect of PDT on growth of distant tumors and the number of T lymphocytes, NK cells, and macrophages in these tumors [90].

Although some studies have focused on the use of genetically engineered cancer vaccines or tumor-associated antigen-primed DCs [91, 92], there is no convincing evidence that these vaccines have an overwhelming advantage over crude vaccines [92]. Although not all tumors are amenable to PDT, either because of size or location, the finding that PDT-generated cancer-cell lysates can act as effective antitumor vaccines has potentially broad clinical implications. Cancer vaccines generated by PDT are therefore of considerable interest, particularly as it is becoming increasingly clear that this approach holds unique prospects for optimally presenting tumor antigens and because of emerging indications that its efficacy can be further potentiated by continued development [93]. While the introduction of PDT vaccines into the clinics and testing on patients is still in a very early phase, much work can still be done on further improvement of the potency of PDT vaccines. Considerable advances can be expected by identifying the most effective adjuvants to be used with PDT vaccines for different types of cancerous lesions [94].

One could conceive of an adjuvant use for PDT vaccines in conjunction with other cancer modalities that do not enhance the host antitumor immune response, such as surgery and/or chemotherapy. The combination of navelbine, PDT, and immune lymphocytes demonstrated a significant synergistic antitumor effect, even though chemotherapy treatment with a low dose of the drug alone was ineffective; the same 
positive results were obtained with the combination of cisplatin, PDT and immune lymphocytes [95]. In addition to combinations with chemotherapy, PDT might also be used in combination with immunomodulation approaches. Recent clinical data also showed that improved clinical outcomes can be obtained through the sequential use of PDT and immunomodulation [96]. Two different immunotherapy agents, $\gamma$-interferon and antibody blocking inhibitory FcyRIIB receptor, were both found to be highly effective in potentiating the curative effect of SL052-PDT with SCCVII tumors. Combining SL052-PDT with FcyRIIB-blocking antibody treatment caused a further increase in the number of cells in tumor-draining lymph nodes and in degranulating $\mathrm{CD}^{+}$cells, suggesting the amplification of the immune response induced by PDT. Vaccines consisting of SCCVII cells treated with SL052-PDT in vitro were effective in reducing growth of established subcutaneous SCCVII tumors [97]. Other studies have investigated the effects of combined approaches using immunostimulants including various microbial preparations that activate Toll-like receptors and other receptors for pathogen-associated molecular patterns, cytokines growth factors, and approaches that target regulatory T-cells [98].

PDT is unique among other approved therapeutic procedures in generating a microenvironment suitable for development of systemic anti-tumor immunity. Furthermore, recent studies have described the emergence of certain promising modalities based on PDT, such photoimmunotherapy [99]. A variant of conventional PDT, vascular-targeted photodynamic therapy (VTP), is about to enter phase III clinical trials for the therapy of prostate cancer; the potential involvement of the immune system may contribute an interesting aspect for the understanding and future development of this treatment modality [100].

\section{CONCLUSION AND FUTURE PERSPECTIVES}

The rising interest in PDT as a promising anticancer treatment is demonstrated by the growing body of literature on the photodynamic mechanism. Understanding the PDT responses of cancer cells will certainly prove crucial to the development of new therapeutic modalities in PDT aimed at increasing the efficiency of cancer-cell killing. Moreover, a better knowledge of the way cancer cells die following PDT will contribute to a better understanding of the impact that different cell-death modalities have on the innate and adaptive immune responses, as well as on therapeutic outcome. Over the more than 35-year history of this treatment, several thousand patients have been treated with PDT [5]. PDT has been employed in the treatment of many tumor types, and its effectiveness as a curative and palliative treatment is well documented, especially for skin cancer. Research into selective delivery of photosensitizers by conjugation to antibodies, use of liposomes as carrier and delivery systems, or new photosensitizers with more specific tumor localization is underway [3]. Combinations of PDT with doxorubicin [101, 102], mitomycin C [103, 104], and inhibitors of angiogenesis [105, 106] have yielded superior PDT responsiveness. The conjunction of imaging technologies, drug-delivery technologies, and a detailed understanding of PDT-related molecular mechanisms will provide an important source for new applications of PDT and for the development of individualized treatments. 


\section{ACKNOWLEDGEMENTS}

This work was supported by Japan Society for the Promotion of Science (JSPS) KAKENHI 23657102.

\section{CONFLICT OF INTEREST}

The authors indicated no potential conflicts of interest.

\section{REFERENCES}

[1] Celli JP, Spring BQ, Rizvi I, Evans CL, Samkoe KS, Verma S, Pogue BW, Hasan T. Imaging and photodynamic therapy: mechanisms, monitoring, and optimization. Chemical Reviews. 2010, 110(5): 2795-2838.

[2] Dolmans DE, Fukumura D, Jain RK. Photodynamic therapy for cancer. Nature Reviews: Cancer. 2003, 3(5): 380-387.

[3] Verma S, Watt GM, Mai Z, Hasan T. Strategies for enhanced photodynamic therapy effects. Photochemistry and Photobiology. 2007, 83(5): 996-1005.

[4] Buytaert E, Dewaele M, Agostinis P. Molecular effectors of multiple cell death pathways initiated by photodynamic therapy. Biochimica et Biophysica Acta. 2007, 1776(1): 86-107.

[5] Castano AP, Mroz P, Hamblin MR. Photodynamic therapy and anti-tumour immunity. Nature Reviews: Cancer. 2006, 6(7): 535-545.

[6] Brown SB, Brown EA, Walker I. The present and future role of photodynamic therapy in cancer treatment. Lancet Oncol. 2004, 5(8): 497-508.

[7] Dougherty TJ. An update on photodynamic therapy applications. Journal of Clinical Laser Medicine and Surgery. 2002, 20(1): 3-7.

[8] Chen Q, Huang Z, Chen H, Shapiro H, Beckers J, Hetzel FW. Improvement of tumor response by manipulation of tumor oxygenation during photodynamic therapy. Photochemistry and Photobiology. 2002, 76(2): 197-203.

[9] Henderson BW, Busch TM, Vaughan LA, Frawley NP, Babich D, Sosa TA, Zollo JD, Dee AS, Cooper MT, Bellnier DA, Greco WR, Oseroff AR. Photofrin photodynamic therapy can significantly deplete or preserve oxygenation in human basal cell carcinomas during treatment, depending on fluence rate. Cancer Research. 2000, 60(3): 525-529.

[10] Sitnik TM, Hampton JA, Henderson BW. Reduction of tumour oxygenation during and after photodynamic therapy in vivo: effects of fluence rate. British Journal of Cancer. 1998, 77(9): 1386-1394.

[11] Engbrecht BW, Menon C, Kachur AV, Hahn SM, Fraker DL. Photofrin-mediated photodynamic therapy induces vascular occlusion and apoptosis in a human sarcoma xenograft model. Cancer Research. 1999, 59(17): 4334-4342.

[12] Fingar VH, Kik PK, Haydon PS, Cerrito PB, Tseng M, Abang E, Wieman TJ. Analysis of acute vascular damage after photodynamic therapy using benzoporphyrin derivative (BPD). British Journal of Cancer. 1999, 79(11-12): 1702-1708.

[13] Keith B, Johnson RS, Simon MC. HIF1alpha and HIF2alpha: sibling rivalry in hypoxic tumour growth and progression. Nature Reviews: Cancer. 2012, 12(1): 9-22.

[14] Semenza GL. Hypoxia-inducible factors in physiology and medicine. Cell. 2012, 148(3): 399-408.

[15] Forsythe JA, Jiang BH, Iyer NV, Agani F, Leung SW, Koos RD, Semenza GL. Activation of vascular endothelial growth factor gene transcription by hypoxia-inducible factor 1. Molecular and Cellular Biology. 1996, 16(9): 4604-4613.

[16] Takenaga K. Angiogenic signaling aberrantly induced by tumor hypoxia. Frontiers in Bioscience. 2011, 16(31-48). 
[17] Deininger MH, Weinschenk T, Morgalla MH, Meyermann R, Schluesener HJ. Release of regulators of angiogenesis following Hypocrellin-A and -B photodynamic therapy of human brain tumor cells. Biochemical and Biophysical Research Communications. 2002, 298(4): 520-530.

[18] Ferrario A, von Tiehl KF, Rucker N, Schwarz MA, Gill PS, Gomer CJ. Antiangiogenic treatment enhances photodynamic therapy responsiveness in a mouse mammary carcinoma. Cancer Research. 2000, 60(15): 4066-4069.

[19] Jiang F, Zhang ZG, Katakowski M, Robin AM, Faber M, Zhang F, Chopp M. Angiogenesis induced by photodynamic therapy in normal rat brains. Photochemistry and Photobiology. 2004, 79(6): 494-498.

[20] Schmidt-Erfurth U, Schlotzer-Schrehard U, Cursiefen C, Michels S, Beckendorf A, Naumann GO. Influence of photodynamic therapy on expression of vascular endothelial growth factor (VEGF), VEGF receptor 3, and pigment epithelium-derived factor. Investigative Ophthalmology and Visual Science. 2003, 44(10): 4473-4480.

[21] Matroule JY, Volanti C, Piette J. NF-kappaB in photodynamic therapy: discrepancies of a master regulator. Photochemistry and Photobiology. 2006, 82(5): 1241-1246.

[22] Agostinis P, Buytaert E, Breyssens H, Hendrickx N. Regulatory pathways in photodynamic therapy induced apoptosis. Photochem Photobiol Sci. 2004, 3(8): 721-729.

[23] Oleinick NL, Morris RL, Belichenko I. The role of apoptosis in response to photodynamic therapy: what, where, why, and how. Photochem Photobiol Sci. 2002, 1(1): 1-21.

[24] Dewaele M, Verfaillie T, Martinet W, Agostinis P. Death and survival signals in photodynamic therapy. Methods in Molecular Biology. 2010, 635(7-33).

[25] Kessel D, Oleinick NL. Photodynamic therapy and cell death pathways. Methods in Molecular Biology. 2010, 635(35-46).

[26] Dewaele M, Martinet W, Rubio N, Verfaillie T, de Witte PA, Piette J, Agostinis P. Autophagy pathways activated in response to PDT contribute to cell resistance against ROS damage. Journal of Cellular and Molecular Medicine. 2011, 15(6): 1402-1414.

[27] Mroz P, Hashmi JT, Huang YY, Lange N, Hamblin MR. Stimulation of anti-tumor immunity by photodynamic therapy. Expert Rev Clin Immunol. 2011, 7(1): 75-91.

[28] Firczuk M, Nowis D, Golab J. PDT-induced inflammatory and host responses. Photochem Photobiol Sci. 2011, 10(5): 653-663.

[29] Danial NN, Korsmeyer SJ. Cell death: critical control points. Cell. 2004, 116(2): 205-219.

[30] Ferri KF, Kroemer G. Organelle-specific initiation of cell death pathways. Nature Cell Biology. 2001, 3(11): E255-263.

[31] Hengartner MO. The biochemistry of apoptosis. Nature. 2000, 407(6805): 770-776.

[32] Tomioka Y, Kushibiki T, Awazu K. Evaluation of oxygen consumption of culture medium and in vitro photodynamic effect of talaporfin sodium in lung tumor cells. Photomed Laser Surg. 2010, 28(3): 385-390.

[33] Piette J, Volanti C, Vantieghem A, Matroule JY, Habraken Y, Agostinis P. Cell death and growth arrest in response to photodynamic therapy with membrane-bound photosensitizers. Biochemical Pharmacology. 2003, 66(8): 1651-1659.

[34] Helbig D, Simon JC, Paasch U. Photodynamic therapy and the role of heat shock protein 70 . International Journal of Hyperthermia. 2011, 27(8): 802-810.

[35] Novina CD, Sharp PA. The RNAi revolution. Nature. 2004, 430(6996): 161-164.

[36] Lu J, Getz G, Miska EA, Alvarez-Saavedra E, Lamb J, Peck D, Sweet-Cordero A, Ebert BL, Mak RH, Ferrando AA, Downing JR, Jacks T, Horvitz HR, Golub TR. MicroRNA expression profiles classify human cancers. Nature. 2005, 435(7043): 834-838.

[37] Kushibiki T. Photodynamic therapy induces microRNA-210 and -296 expression in HeLa cells. $J$ Biophotonics. 2010, 3(5-6): 368-372. 
[38] Giannakakis A, Sandaltzopoulos R, Greshock J, Liang S, Huang J, Hasegawa K, Li C, O’BrienJenkins A, Katsaros D, Weber BL, Simon C, Coukos G, Zhang L. miR-210 links hypoxia with cell cycle regulation and is deleted in human epithelial ovarian cancer. Cancer Biol Ther. 2008, 7(2): 255-264.

[39] Wurdinger T, Tannous BA, Saydam O, Skog J, Grau S, Soutschek J, Weissleder R, Breakefield XO, Krichevsky AM. miR-296 regulates growth factor receptor overexpression in angiogenic endothelial cells. Cancer Cell. 2008, 14(5): 382-393.

[40] Cheng AM, Byrom MW, Shelton J, Ford LP. Antisense inhibition of human miRNAs and indications for an involvement of miRNA in cell growth and apoptosis. Nucleic Acids Res. 2005, 33(4): $1290-1297$.

[41] Thong PS, Olivo M, Kho KW, Bhuvaneswari R, Chin WW, Ong KW, Soo KC. Immune response against angiosarcoma following lower fluence rate clinical photodynamic therapy. Journal of Environmental Pathology, Toxicology and Oncology. 2008, 27(1): 35-42.

[42] Kabingu E, Oseroff AR, Wilding GE, Gollnick SO. Enhanced systemic immune reactivity to a Basal cell carcinoma associated antigen following photodynamic therapy. Clinical Cancer Research. 2009, 15(13): 4460-4466.

[43] Kawczyk-Krupka A, Czuba Z, Szliszka E, Krol W, Sieron A. The role of photosensitized macrophages in photodynamic therapy. Oncology Reports. 2011, 26(1): 275-280.

[44] Brackett CM, Gollnick SO. Photodynamic therapy enhancement of anti-tumor immunity. Photochem Photobiol Sci. 2011, 10(5): 649-652.

[45] Sun J, Cecic I, Parkins CS, Korbelik M. Neutrophils as inflammatory and immune effectors in photodynamic therapy-treated mouse SCCVII tumours. Photochem Photobiol Sci. 2002, 1(9): 690-695.

[46] Gollnick SO, Evans SS, Baumann H, Owczarczak B, Maier P, Vaughan L, Wang WC, Unger E, Henderson BW. Role of cytokines in photodynamic therapy-induced local and systemic inflammation. British Journal of Cancer. 2003, 88(11): 1772-1779.

[47] Kammerer R, Buchner A, Palluch P, Pongratz T, Oboukhovskij K, Beyer W, Johansson A, Stepp H, Baumgartner R, Zimmermann W. Induction of immune mediators in glioma and prostate cancer cells by non-lethal photodynamic therapy. PLoS One. 2011, 6(6): e21834.

[48] Kousis PC, Henderson BW, Maier PG, Gollnick SO. Photodynamic therapy enhancement of antitumor immunity is regulated by neutrophils. Cancer Research. 2007, 67(21): 10501-10510.

[49] Tanaka M, Mroz P, Dai T, Huang L, Morimoto Y, Kinoshita M, Yoshihara Y, Nemoto K, Shinomiya N, Seki S, Hamblin MR. Photodynamic therapy can induce a protective innate immune response against murine bacterial arthritis via neutrophil accumulation. PLoS One. 2012, 7(6): e39823.

[50] Banchereau J, Palucka AK. Dendritic cells as therapeutic vaccines against cancer. Nature Reviews: Immunology. 2005, 5(4): 296-306.

[51] Boczkowski D, Nair SK, Snyder D, Gilboa E. Dendritic cells pulsed with RNA are potent antigenpresenting cells in vitro and in vivo. Journal of Experimental Medicine. 1996, 184(2): 465-472.

[52] Condon C, Watkins SC, Celluzzi CM, Thompson K, Falo LD, Jr. DNA-based immunization by in vivo transfection of dendritic cells. Nature Medicine. 1996, 2(10): 1122-1128.

[53] Fields RC, Shimizu K, Mule JJ. Murine dendritic cells pulsed with whole tumor lysates mediate potent antitumor immune responses in vitro and in vivo. Proceedings of the National Academy of Sciences of the United States of America. 1998, 95(16): 9482-9487.

[54] Figdor CG, de Vries IJ, Lesterhuis WJ, Melief CJ. Dendritic cell immunotherapy: mapping the way. Nature Medicine. 2004, 10(5): 475-480

[55] Gong J, Chen D, Kashiwaba M, Kufe D. Induction of antitumor activity by immunization with fusions of dendritic and carcinoma cells. Nature Medicine. 1997, 3(5): 558-561.

[56] Hsu FJ, Benike C, Fagnoni F, Liles TM, Czerwinski D, Taidi B, Engleman EG, Levy R. Vaccination of patients with B-cell lymphoma using autologous antigen-pulsed dendritic cells. Nature Medicine. 1996, 2(1): 52-58. 
[57] Song W, Kong HL, Carpenter H, Torii H, Granstein R, Rafii S, Moore MA, Crystal RG. Dendritic cells genetically modified with an adenovirus vector encoding the cDNA for a model antigen induce protective and therapeutic antitumor immunity. Journal of Experimental Medicine. 1997, 186(8): $1247-1256$.

[58] Steinman RM, Pope M. Exploiting dendritic cells to improve vaccine efficacy. Journal of Clinical Investigation. 2002, 109(12): 1519-1526.

[59] Henderson BW, Gollnick SO, Snyder JW, Busch TM, Kousis PC, Cheney RT, Morgan J. Choice of oxygen-conserving treatment regimen determines the inflammatory response and outcome of photodynamic therapy of tumors. Cancer Research. 2004, 64(6): 2120-2126.

[60] Reis e Sousa C. Activation of dendritic cells: translating innate into adaptive immunity. Current Opinion in Immunology. 2004, 16(1): 21-25.

[61] Sur BW, Nguyen P, Sun CH, Tromberg BJ, Nelson EL. Immunophototherapy using PDT combined with rapid intratumoral dendritic cell injection. Photochemistry and Photobiology. 2008, 84(5): $1257-1264$

[62] Korbelik M, Sun J, Cecic I. Photodynamic therapy-induced cell surface expression and release of heat shock proteins: relevance for tumor response. Cancer Research. 2005, 65(3): 1018-1026.

[63] Korbelik M, Merchant S. Photodynamic therapy-generated cancer vaccine elicits acute phase and hormonal response in treated mice. Cancer Immunology, Immunotherapy. 2012, 61(9): 1387-1394.

[64] Jung NC, Kim HJ, Kang MS, Lee JH, Song JY, Seo HG, Bae YS, Lim DS. Photodynamic therapymediated DC immunotherapy is highly effective for the inhibition of established solid tumors. Cancer Letters. 2012, 324(1): 58-65.

[65] Jalili A, Makowski M, Switaj T, Nowis D, Wilczynski GM, Wilczek E, Chorazy-Massalska M, Radzikowska A, Maslinski W, Bialy L, Sienko J, Sieron A, Adamek M, Basak G, Mroz P, Krasnodebski IW, Jakobisiak M, Golab J. Effective photoimmunotherapy of murine colon carcinoma induced by the combination of photodynamic therapy and dendritic cells. Clinical Cancer Research. 2004, 10(13): 4498-4508.

[66] Gollnick SO, Vaughan L, Henderson BW. Generation of effective antitumor vaccines using photodynamic therapy. Cancer Research. 2002, 62(6): 1604-1608.

[67] Kushibiki T, Tajiri T, Tomioka Y, Awazu K. Photodynamic therapy induces interleukin secretion from dendritic cells. Int J Clin Exp Med. 2010, 3(2): 110-114.

[68] Dougherty TJ, Gomer CJ, Henderson BW, Jori G, Kessel D, Korbelik M, Moan J, Peng Q. Photodynamic therapy. Journal of the National Cancer Institute. 1998, 90(12): 889-905.

[69] Kishimoto T. The biology of interleukin-6. Blood. 1989, 74(1): 1-10.

[70] Mule JJ, Custer MC, Travis WD, Rosenberg SA. Cellular mechanisms of the antitumor activity of recombinant IL-6 in mice. Journal of Immunology. 1992, 148(8): 2622-2629.

[71] Kick G, Messer G, Goetz A, Plewig G, Kind P. Photodynamic therapy induces expression of interleukin 6 by activation of AP-1 but not NF-kappa B DNA binding. Cancer Research. 1995, 55(11): 2373-2379.

[72] Evans S, Matthews W, Perry R, Fraker D, Norton J, Pass HI. Effect of photodynamic therapy on tumor necrosis factor production by murine macrophages. Journal of the National Cancer Institute. 1990, 82(1): 34-39.

[73] Anderson C, Hrabovsky S, McKinley Y, Tubesing K, Tang HP, Dunbar R, Mukhtar H, Elmets CA. Phthalocyanine photodynamic therapy: disparate effects of pharmacologic inhibitors on cutaneous photosensitivity and on tumor regression. Photochemistry and Photobiology. 1997, 65(5): 895-901.

[74] Vincek V, Kurimoto I, Medema JP, Prieto E, Streilein JW. Tumor necrosis factor alpha polymorphism correlates with deleterious effects of ultraviolet B light on cutaneous immunity. Cancer Research. 1993, 53(4): 728-732.

[75] Dougherty GJ, Thacker JD, Lavey RS, Belldegrun A, McBride WH. Inhibitory effect of locally produced and exogenous interleukin- 6 on tumor growth in vivo. Cancer Immunology, Immunotherapy. 1994, 38(5): 339-345. 
[76] Mullen CA, Coale MM, Levy AT, Stetler-Stevenson WG, Liotta LA, Brandt S, Blaese RM. Fibrosarcoma cells transduced with the IL- 6 gene exhibited reduced tumorigenicity, increased immunogenicity, and decreased metastatic potential. Cancer Research. 1992, 52(21): 6020-6024.

[77] Brackett CM, Owczarczak B, Ramsey K, Maier PG, Gollnick SO. IL-6 potentiates tumor resistance to photodynamic therapy (PDT). Lasers in Surgery and Medicine. 2011, 43(7): 676-685.

[78] Luna MC, Wong S, Gomer CJ. Photodynamic therapy mediated induction of early response genes. Cancer Research. 1994, 54(5): 1374-1380.

[79] Kick G, Messer G, Plewig G, Kind P, Goetz AE. Strong and prolonged induction of c-jun and c-fos proto-oncogenes by photodynamic therapy. British Journal of Cancer. 1996, 74(1): 30-36.

[80] Tracy EC, Bowman MJ, Henderson BW, Baumann H. Interleukin-1alpha is the major alarmin of lung epithelial cells released during photodynamic therapy to induce inflammatory mediators in fibroblasts. British Journal of Cancer. 2012,

[81] Belicha-Villanueva A, Riddell J, Bangia N, Gollnick SO. The effect of photodynamic therapy on tumor cell expression of major histocompatibility complex (MHC) class I and MHC class I-related molecules. Lasers in Surgery and Medicine. 2012, 44(1): 60-68.

[82] Korbelik M, Sun J. Photodynamic therapy-generated vaccine for cancer therapy. Cancer Immunology, Immunotherapy. 2006, 55(8): 900-909.

[83] Stott B, Korbelik M. Activation of complement C3, C5, and C9 genes in tumors treated by photodynamic therapy. Cancer Immunology, Immunotherapy. 2007, 56(5): 649-658.

[84] Li F, Cheng Y, Lu J, Hu R, Wan Q, Feng H. Photodynamic therapy boosts anti-glioma immunity in mice: a dependence on the activities of T cells and complement C3. Journal of Cellular Biochemistry. 2011, 112(10): 3035-3043.

[85] Giomi B, Pagnini F, Cappuccini A, Bianchi B, Tiradritti L, Zuccati G. Immunological activity of photodynamic therapy for genital warts. British Journal of Dermatology. 2011, 164(2): 448-451.

[86] Yusuf N, Katiyar SK, Elmets CA. The immunosuppressive effects of phthalocyanine photodynamic therapy in mice are mediated by CD4+ and CD8+ T cells and can be adoptively transferred to naive recipients. Photochemistry and Photobiology. 2008, 84(2): 366-370.

[87] Mroz P, Szokalska A, Wu MX, Hamblin MR. Photodynamic therapy of tumors can lead to development of systemic antigen-specific immune response. PLoS One. 2010, 5(12): e15194.

[88] Thong PS, Ong KW, Goh NS, Kho KW, Manivasager V, Bhuvaneswari R, Olivo M, Soo KC. Photodynamic-therapy-activated immune response against distant untreated tumours in recurrent angiosarcoma. Lancet Oncol. 2007, 8(10): 950-952.

[89] Kabingu E, Vaughan L, Owczarczak B, Ramsey KD, Gollnick SO. CD8+ T cell-mediated control of distant tumours following local photodynamic therapy is independent of CD4+ T cells and dependent on natural killer cells. British Journal of Cancer. 2007, 96(12): 1839-1848.

[90] van Duijnhoven FH, Aalbers RI, Rovers JP, Terpstra OT, Kuppen PJ. Immunological aspects of photodynamic therapy of liver tumors in a rat model for colorectal cancer. Photochemistry and Photobiology. 2003, 78(3): 235-240.

[91] Banchereau J, Schuler-Thurner B, Palucka AK, Schuler G. Dendritic cells as vectors for therapy. Cell. 2001, 106(3): 271-274.

[92] Sinkovics JG, Horvath JC. Vaccination against human cancers (review). International Journal of Oncology. 2000, 16(1): 81-96.

[93] Korbelik M. Photodynamic therapy-generated cancer vaccines. Methods in Molecular Biology. 2010, 635(147-153).

[94] Korbelik M. Cancer vaccines generated by photodynamic therapy. Photochem Photobiol Sci. 2011, 10(5): 664-669.

[95] Canti G, Calastretti A, Bevilacqua A, Reddi E, Palumbo G, Nicolin A. Combination of photodynamic therapy + immunotherapy + chemotherapy in murine leukiemia. Neoplasma. 2010, 57(2): 184-188. 
[96] Wang XL, Wang HW, Yuan KH, Li FL, Huang Z. Combination of photodynamic therapy and immunomodulation for skin diseases-update of clinical aspects. Photochem Photobiol Sci. 2011, 10(5): 704-711.

[97] Korbelik M, Merchant S, Huang N. Exploitation of immune response-eliciting properties of hypocrellin photosensitizer SL052-based photodynamic therapy for eradication of malignant tumors. Photochemistry and Photobiology. 2009, 85(6): 1418-1424.

[98] St Denis TG, Aziz K, Waheed AA, Huang YY, Sharma SK, Mroz P, Hamblin MR. Combination approaches to potentiate immune response after photodynamic therapy for cancer. Photochem Photobiol Sci. 2011, 10(5): 792-801.

[99] Garg AD, Nowis D, Golab J, Agostinis P. Photodynamic therapy: illuminating the road from cell death towards anti-tumour immunity. Apoptosis. 2010, 15(9): 1050-1071.

[100] Preise D, Scherz A, Salomon Y. Antitumor immunity promoted by vascular occluding therapy: lessons from vascular-targeted photodynamic therapy (VTP). Photochem Photobiol Sci. 2011, 10(5): 681-688.

[101] Snyder JW, Greco WR, Bellnier DA, Vaughan L, Henderson BW. Photodynamic therapy: a means to enhanced drug delivery to tumors. Cancer Research. 2003, 63(23): 8126-8131.

[102] Kirveliene V, Grazeliene G, Dabkeviciene D, Micke I, Kirvelis D, Juodka B, Didziapetriene J. Schedule-dependent interaction between Doxorubicin and mTHPC-mediated photodynamic therapy in murine hepatoma in vitro and in vivo. Cancer Chemotherapy and Pharmacology. 2006, 57(1): 65-72.

[103] Baas P, van Geel IP, Oppelaar H, Meyer M, Beynen JH, van Zandwijk N, Stewart FA. Enhancement of photodynamic therapy by mitomycin C: a preclinical and clinical study. British Journal of Cancer. 1996, 73(8): 945-951.

[104] Chen B, Ahmed B, Landuyt W, Ni Y, Gaspar R, Roskams T, de Witte PA. Potentiation of photodynamic therapy with hypericin by mitomycin $\mathrm{C}$ in the radiation-induced fibrosarcoma-1 mouse tumor model. Photochemistry and Photobiology. 2003, 78(3): 278-282.

[105] Zhou Q, Olivo M, Lye KY, Moore S, Sharma A, Chowbay B. Enhancing the therapeutic responsiveness of photodynamic therapy with the antiangiogenic agents SU5416 and SU6668 in murine nasopharyngeal carcinoma models. Cancer Chemotherapy and Pharmacology. 2005, 56(6): 569-577.

[106] Ferrario A, Fisher AM, Rucker N, Gomer CJ. Celecoxib and NS-398 enhance photodynamic therapy by increasing in vitro apoptosis and decreasing in vivo inflammatory and angiogenic factors. Cancer Research. 2005, 65(20): 9473-9478. 



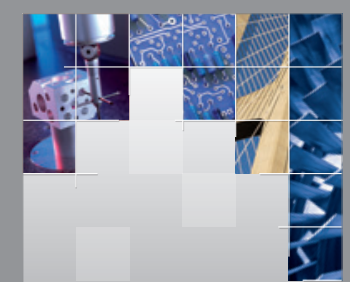

\section{Enfincering}
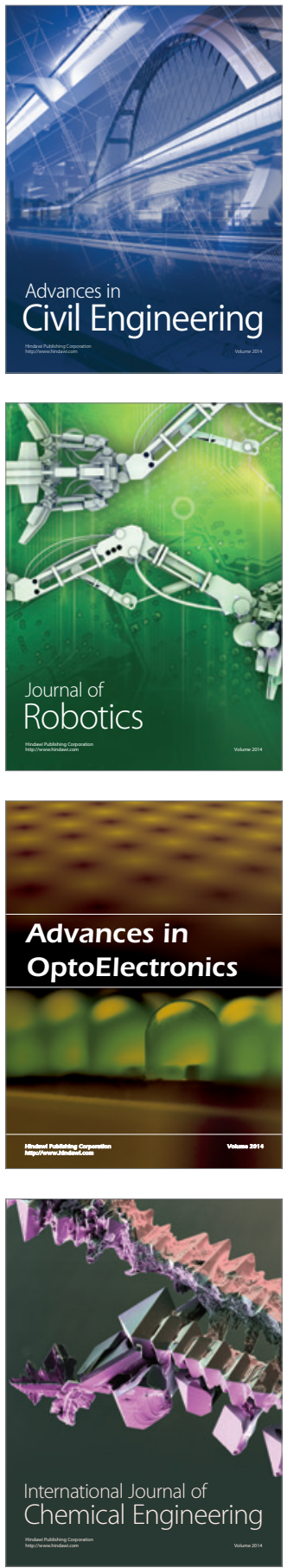

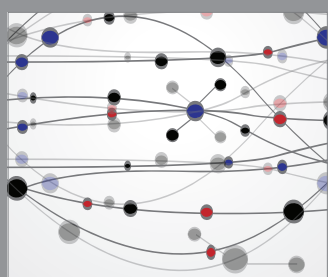

The Scientific World Journal

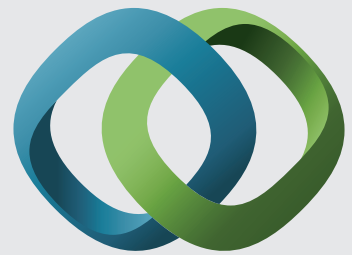

\section{Hindawi}

Submit your manuscripts at

http://www.hindawi.com
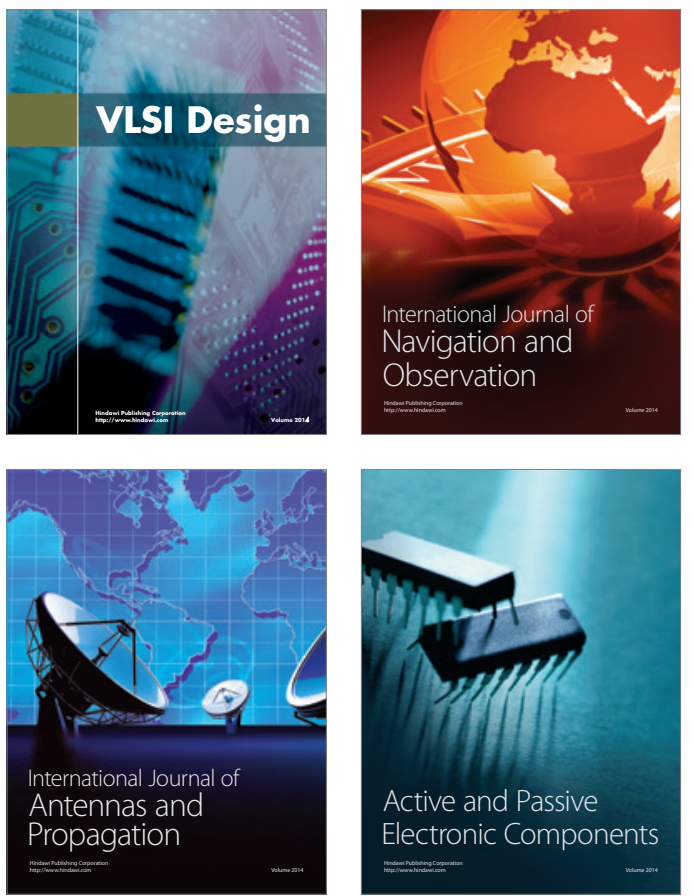
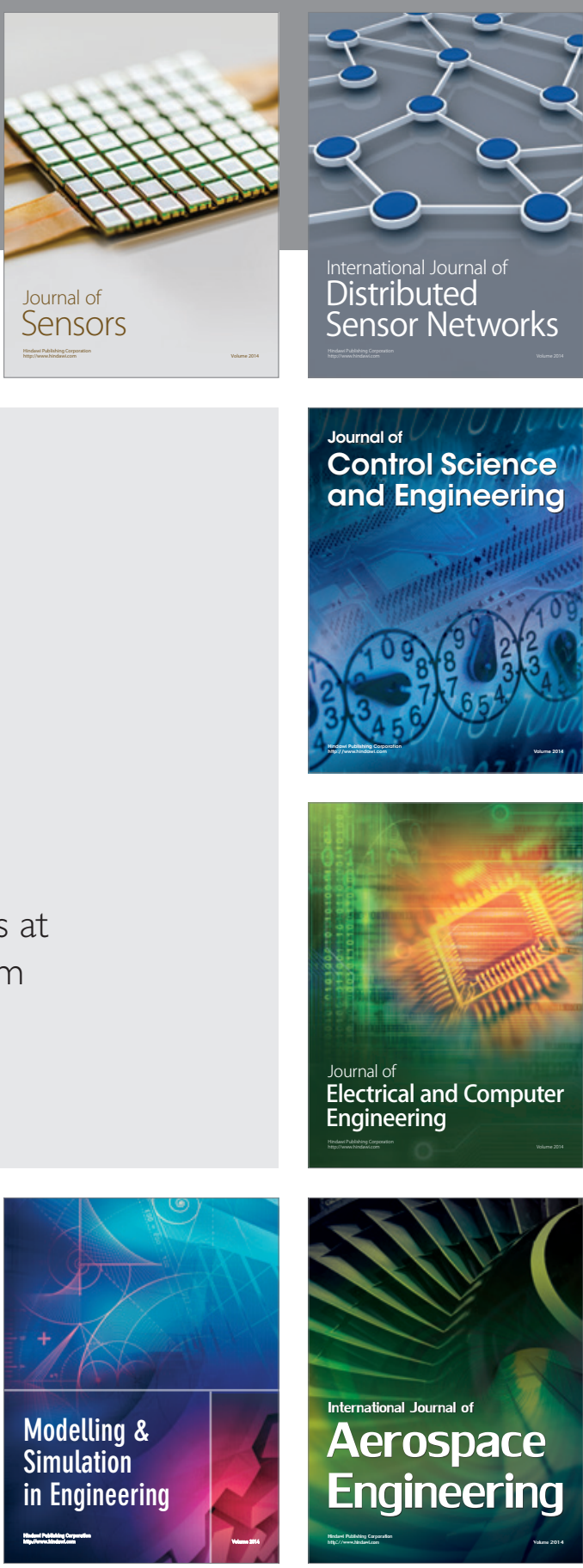

International Journal of

Distributed

Sensor Networks

Journal of

Control Science

and Engineering
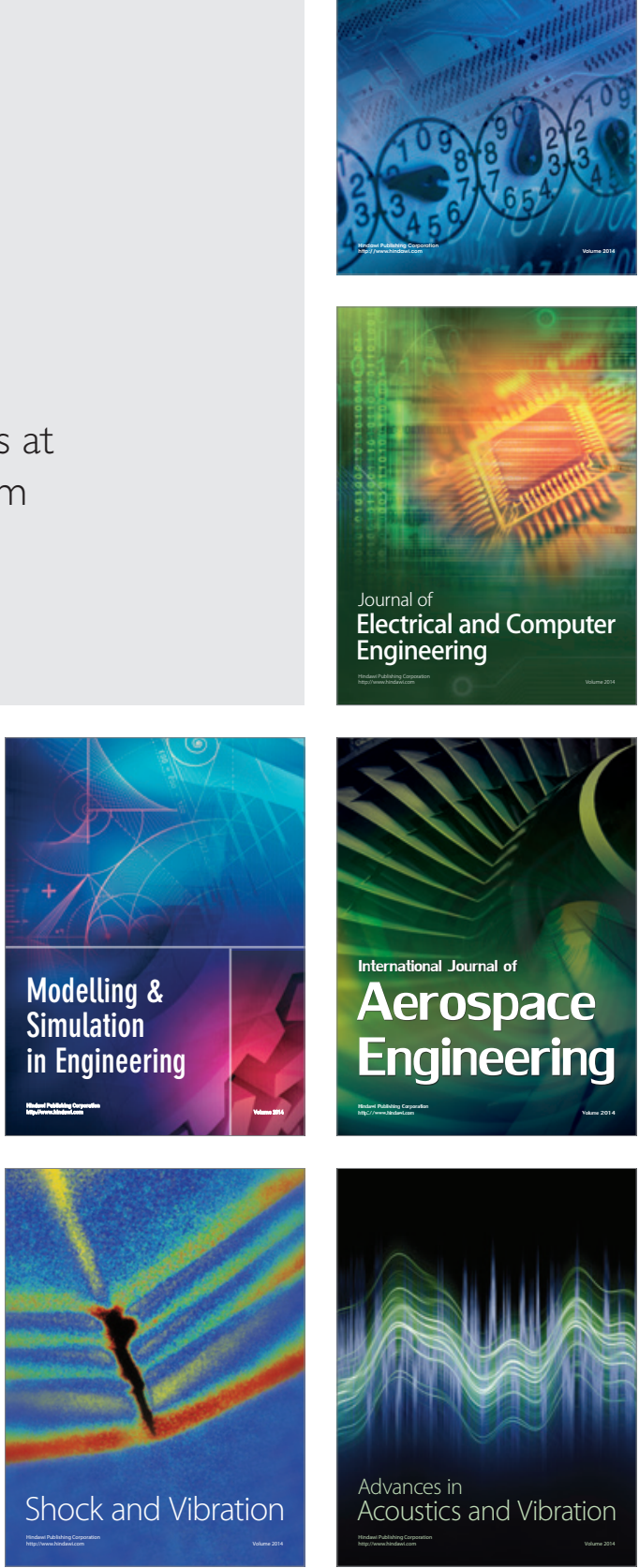